\title{
ANALISA KANDUNGAN TIMBAL (Pb) PADA SAYURAN HIJAU YANG DIJUAL DI PASAR TRADISIONAL KAMPUNG LALANG MEDAN
}

\author{
Halimah Fitriani Pane \\ Jurusan Analis Kesehatan Poltekkes Kemenkes Medan \\ Jl.Willem Iskandar. Pasar V Barat. No 6. Medan Estate.20371 \\ Halimah.fitriani@gmail.com
}

\begin{abstract}
ABSTRAK
Sayuran merupakan sumber vitamin dan mineral yang dibutuhkan manusia. Namun, banyak jenis sayuran yang beredar dijual di pasar pinggir jalan tidak aman untuk dikonsumsi karena berbahaya bagi kesehatan manusia, diduga sayuran tersebut terkontaminasi logam berat seperti timbal. Tujuan penelitian ini adalah untuk menentukan kandungan timbal dalam sayuran hijau yang dijual di pasar tradisional Kampung Lalang Medan. Jenis penelitian ini merupakan observasi dan bersifat deskriptif. Sampel yang digunakan merupakan total populasi yang berjumlah 7 jenis sayuran yaitu bayam hijau, kangkung, genjer, sawi hijau, daun singkong, pakchoi, brokoli. Penelitian dilakukan di Laboratorium Kesehatan Daerah Medan. Persiapan sampel dilakukan dengan penghancuran kering. Analisis kuantitatif dilakukan dengan spektrofotometri serapan atom (AAS) dengan nyala udara-asetilena pada panjang gelombang untuk timbal adalah $283,3 \mathrm{~nm}$. Hasil penelitian ini menunjukkan kadar logam timbal pada sayuran yang telah dicuci, bayam hijau $0,9816 \mathrm{mg} / \mathrm{kg}$, kale $1,0246 \mathrm{mg} / \mathrm{kg}$, genjer 0,8654 $\mathrm{mg} / \mathrm{kg}$, sawi hijau 0,9681 mg / kg, daun singkong0.7355 mg / kg, pakchoi $1.0521 \mathrm{mg} / \mathrm{kg}$, brokoli $0,7502 \mathrm{mg} / \mathrm{kg}$. Semua sampel nabati di atas nilai maksimum pencemaran timbal yang diizinkan oleh SNI 7387 tahun 2009 yaitu $0,5 \mathrm{mg} / \mathrm{kg}$.
\end{abstract}

Kata kunci: Sayuran hijau, Timbal, Kesehatan, Spektrofotometri, Nabati

\begin{abstract}
Vegetables are a source of vitamins and minerals that humans need. However, many types of vegetables that are sold on the roadside market are not safe for consumption because they are harmful to human health, allegedly they are contaminated with heavy metals such as lead. The purpose of this study was to determine the lead content in green vegetables sold in the traditional market of Kampung Lalang Medan. This type of research is observational and descriptive. The sample used was a total population of 7 types of vegetables namely green spinach, kale, genjer, mustard greens, cassava leaves, pakchoi, broccoli. The study was conducted at the Medan Regional Health Laboratory. Sample preparation is done by dry crushing. Quantitative analysis was performed with atomic absorption spectrophotometry $(A A S)$ with the air-acetylene flame at wavelength for lead being $283.3 \mathrm{~nm}$. The results of this study showed the levels of lead metal in washed vegetables, green spinach $0.9816 \mathrm{mg} /$ $\mathrm{kg}$, kale $1.0246 \mathrm{mg} / \mathrm{kg}$, genjer $0.8654 \mathrm{mg} / \mathrm{kg}$, mustard green $0.9681 \mathrm{mg} / \mathrm{kg}$, cassava leaves0 7355 $\mathrm{mg} / \mathrm{kg}$, pakchoi $1.0521 \mathrm{mg} / \mathrm{kg}$, broccoli $0.7502 \mathrm{mg} / \mathrm{kg}$. All vegetable samples above the maximum value of lead pollution allowed by SNI 7387 in 2009 are $0.5 \mathrm{mg} / \mathrm{kg}$.
\end{abstract}

Keywords: Green vegetables, Lead, Health, Spectrophotometry, Vegetable 


\section{PENDAHULUAN}

Sayur - sayuran merupakan bagian dari tanaman yang umum dimakan untuk memenuhi kebutuhan gizi seseorang. Sayuran perlu di konsumsi setiap hari agar tubuh kita tetap sehat karena di dalamnya tidak hanya mengandung serat saja namun

juga banyak mengandung zat gizi yang penting bagi kesehatan tubuh seperti berbagai macam vitamin dan mineral. (Yuliarti, 2008).

Sayuran sangat penting dikonsumsi untuk kesehatan masyarakat. Nilai gizi makanan kita sehari-hari dapat diperbaiki, karena sayuran merupakan sumber vitamin, mineral, protein nabati dan serat. Menurut hasil Seminar Gizi tahun 1963 dan Workshop of Food tahun 1968, setiap hari orang Indonesia memerlukan sayuran sebanyak $150 \mathrm{~g}$ berat bersih/orang/hari dalam menu makanannya (Sunarjono, 2015).

Sayuran merupakan sumber pangan yang mengandung banyak vitamin dan mineral yang secara langsung berperan penting dalam meningkatkan kesehatan. Oleh karena itu, higienitas dan keamanan sayuran yang dikonsumsi menjadi sangat penting agar tidak menimbulkan gangguan kesehatan. Namun, banyak jenis sayuran yang beredar di masyarakat tidak terjamin keamanannya karena diduga telah terkontaminasi logam-logam berat seperti timbal $(\mathrm{Pb})$ (Widaningrum, dkk., 2007).

Logam berat ialah unsur logam dengan berat molekul tinggi. Dalam kadar rendah logam berat pada umumnya sudah beracun bagi tumbuhan, termasuk manusia. Logam timbal $(\mathrm{Pb})$ sangat berbahaya bagi manusia karena merupakan zat beracun yang tidak bisa dihancurkan atau diubah bentuknya. (Widowati, dkk, 2008). Pencemaran timbal $(\mathrm{Pb})$ pada sayuran setelah pasca panen terjadi selama pengangkutan, penjualan dan distribusi (Widaningrum, dkk., 2007).

Di Indonesia, kadar logam berat yang cukup tinggi pada sayuran sudah semestinya mendapat perhatian serius dari semua pihak, terutama pada sayur-sayuran yang ditanam di pinggir jalan raya. Logam berat yang masuk ke dalam tubuh manusia akan melakukan interaksi antara lain dengan enzim, protein, DNA, serta metabolit lainnya. Adanya logam berat pada jumlah yang berlebihan dalam tubuh akan berpengaruh buruk terhadap tubuh (Charlena, 2004).
Pencemaran $\mathrm{Pb}$ yang berasal dari asap kendaraan bermotor juga diperoleh dalam sayur kangkung dan bayam yang ditanam dekat dengan jalan raya. Hasil penelitian ini menunjukan bahwa sayur bayam memiliki kandungan logam $\mathrm{Pb}$ lebih tinggi jika dibandingkan dengan sayur kangkung yaitu sebesar 0,4234 mg/Kg (Erdayanti, 2015). Akumulasi logam timbal $(\mathrm{Pb})$ pada daun lebih tinggi bila terpapar asap kendaraan dengan jarak yang lebih dekat dan waktu pemaparan yang lebih lama (Mariti, 2005).

Menurut SNI 7387 tahun 2009 : Batas Cemaran Logam Berat Timbal $(\mathrm{Pb})$ dalam Sayuran adalah $0,5 \mathrm{mg} / \mathrm{kg}$. Hal ini tentu saja harus diwaspadai karena cemaran timbal dapat mengurangi kualitas sayur-sayuran yang dikonsumsi dan akan berbahaya bagi kesehatan masyarakat apabila cemaran tersebut melewati batas toksiknya.

Hasil penelitian yang dilakukan Pasaribu (2004) menunjukkan bahwa kadar timbal $(\mathrm{Pb})$ pada beberapa sayuran di Kota Medan dan Brastagi yaitu : Bayam sebelum dicuci sebesar: $2,170 \mathrm{mg} / \mathrm{kg}$ sesudah dicuci sebesar: $1,745 \mathrm{mg} / \mathrm{kg}$, Kangkung sebelum dicuci sebesar : 2,140 mg/kg sesudah dicuci sebesar : 1,695 mg/kg, Daun Singkong sebelum dicuci sebesar: 2,295 $\mathrm{mg} / \mathrm{kg}$ sesudah dicuci sebesar: $1,885 \mathrm{mg} / \mathrm{kg}$, Sawi sebelum Dicuci sebesar : $2,150 \mathrm{mg} / \mathrm{kg}$ sesudah dicuci sebesar: $1,700 \mathrm{mg} / \mathrm{kg}$, Kol sebelum dicuci sebesar : $1,895 \mathrm{mg} / \mathrm{kg}$ sesudah dicuci sebesar: 1,645 $\mathrm{mg} / \mathrm{kg}$, Kembang Kol sebelum dicuci sebesar: $1,970 \mathrm{mg} / \mathrm{kg}$ sesudah dicuci sebesar: 1,660 $\mathrm{mg} / \mathrm{kg}$. Pada sayuran bayam, kangkung, daun singkong dan sawi sebelum dicuci kadar timbal yang terkandung sudah melebihi nilai ambang batas kandungan timbal dalam sayuran.

Berdasarkan survei dilokasi bahwa, Kelurahan Kampung Lalang merupakan pintu gerbang bagian barat Kota Medan yang dilintasi Jalan Lintas Sumatera (Jalinsum) dari arah Binjai, Stabat dan Aceh, banyak kendaraan yang melintas setiap harinya seperti truk pengangkut barang, mobil pribadi, angkutan umum, becak motor dan sepeda motor. Hal itu menjadikan kawasan tersebut menjadi salah satu jalur padat lalu lintas ditambah dengan banyaknya pedagang yang berjualan di sepanjang jalan raya tidak terkecuali pedagang sayur yang menjajakan sayuran dagangannya dalam kondisi terbuka. Hal ini dapat mengakibatkan kontaminasi asap kendaraan bermotor yang mengandung timbal terhadap 
sayuran hijau yang dijual di pasar Kampung Lalang. Sehingga peneliti tertarik untuk menganalisa apakah sayuran hijau yang di jual di Pasar Tradisional Kampung Lalang Medan mengandung timbal $(\mathrm{Pb})$.

\section{PERMASALAHAN}

Sayuran hijau yang dijual di pasar kampung lalang Medan berada di pinggir jalan di mana banyak dilalui kendaraan baik sepeda motor, becak, mobil, truk, bus. Sayuran tersebut tidak menggunakan penutup sehingga memungkinkan debu, asap kendaraan akan mencemari sayuran tersebut.

\section{TUJUAN PENELITIAN}

- Untuk mengidentifikasi kandungan Timbal $(\mathrm{Pb})$ pada sayur

- Untuk menentukan kadar Timbal $(\mathrm{Pb})$ di dalam sayur yang dijual di Pasar Tradisional Kampung Lalang Medan.

\section{METODE PENELITIAN}

Metode penelitian yang digunakan pada penelitian ini bersifat deskriptif dengan menggunakan metode Spektrofotometri Serapan Atom (SSA).

\section{HASIL DAN PEMBAHASAN}

Tabel 1. Hasil Pemeriksaan Konsentrasi Pb pada Sayuran Hijau yang Dijual di Pasar Tradisional Kampung Lalang Medan

\begin{tabular}{cccc}
\hline Kode Sampel & Nama Sampel & $\begin{array}{c}\text { Absorbansi } \\
(\mathrm{A})\end{array}$ & $\begin{array}{c}\text { Konsentrasi Pb } \\
(\mathrm{ppm})\end{array}$ \\
\hline PM 0196 & Bayam Hijau & 0.0068 & 0,4913 \\
PM 0197 & Kangkung & 0.0071 & 0,5130 \\
PM 0198 & Genjer & 0.0060 & 0,4333 \\
PM 0199 & Sawi Hijau & 0.0067 & 0,4841 \\
PM 0200 & Daun Singkong & 0.0051 & 0,3681 \\
PM 0201 & Pakchoi & 0.0073 & 0,5275 \\
PM 0202 & Brokoli & 0.0052 & 0,3754 \\
\hline
\end{tabular}

Tabel 2. Hasil Pemeriksaan Kadar Pb pada Sayuran Hijau yang Dijual di Pasar Tradisional Kampung Lalang Medan

\begin{tabular}{cccc}
\hline Kode Sampel & Nama Sampel & $\begin{array}{c}\text { Berat Sampel } \\
(\mathrm{gr})\end{array}$ & $\begin{array}{c}\text { Kadar Pb } \\
(\mathrm{mg} / \mathrm{kg})\end{array}$ \\
\hline PM 0196 & Bayam Hijau & 50,0485 & 0,9816 \\
PM 0197 & Kangkung & 50,0655 & 1,0246 \\
PM 0198 & Genjer & 50,0672 & 0,8654 \\
PM 0199 & Sawi Hijau & 50,0023 & 0,9681 \\
PM 0200 & Daun Singkong & 50,0464 & 0,7355 \\
PM 0201 & Pakchoi & 50,1336 & 1,0521 \\
PM 0202 & Brokoli & 50,0387 & 0,7502 \\
\hline
\end{tabular}


Tabel 1. Menunjukkan bahwa semua sampel mengandung timbal dengan kadar yang berbeda-beda. Berdasarkan hasil perhitungan yang dilakukan, kadar timbal tertinggi hingga terendah yang terdapat dalam sampel sayuran sebelum dicuci yaitu, Pakchoi 1,0521 mg/kg, Kangkung 1,0246 mg/kg, Bayam hijau 0,9816 $\mathrm{mg} / \mathrm{kg}$, Sawi hijau $0,9681 \mathrm{mg} / \mathrm{kg}$, Genjer 0,8654 $\mathrm{mg} / \mathrm{kg}$, Brokoli 0,7502 mg/kg, Daun singkong $0,7355 \mathrm{mg} / \mathrm{kg}$. Semua sampel sayuran sudah melampaui batas nilai maksimum cemaran logam timbal yang diperbolehkan oleh SNI 7387 tahun 2009 yaitu $0.5 \mathrm{mg} / \mathrm{kg}$, sehingga kadar timbal pada sayuran yang diperiksa dapat dikatakan telah berbahaya bagi tubuh manusia. Besarnya kandungan timbal yang terdapat dalam setiap sampel berasal dari gas buangan kendaraan bermotor yang akan terbang ke udara, dimana sebagian akan menempel pada sayuran yang di jual di pinggir jalan raya.

\section{PEMBAHASAN}

Sumber pencemar logam timbal terbesar berasal dari asap kendaraan bermotor, sehingga apabila sayuran ditanam atau dijual dipinggir jalan raya maka akan menjadi mediator penyebaran logam berat timbal. Tanaman yang menjadi mediator penyebaran logam berat pada makhluk hidup, menyerap logam berat melalui akar dan daun (stomata) yang selanjutnya akan masuk ke dalam siklus rantai makanan (Darmono, 2005).

Kadar timbal pada sayuran pakchoi, kangkung, bayam hijau, sawi hijau dan genjer lebih tinggi dibandingkan dengan daun singkong dan brokoli. Hal ini disebabkan karena sayuran pakchoi, kangkung, bayam hijau, sawi hijau dan genjer mempunyai luas permukaan daun yang lebih lebar. Hal ini didukung oleh hasil penelitian Eka et al. (2015) menyatakan bahwa luas permukaan dan tekstur daun yang kasar serta berbulu juga mempengaruhi kadar timbal jerapan yang menempel pada sayuran .

Apabila kita mengkonsumsi sayuran yang mengandung timbal secara terus-menerus akan mengakibatkan penumpukan timbal dalam tubuh terutama dalam ginjal, hati dan jaringan yang memiliki dampak berbahaya yaitu dapat menghambat aktivitas enzim yang terlibat dalam pembentukan hemoglobin ( $\mathrm{Hb})$, merusak jaringan saraf otak, dan gangguan gastrointestinal (Widowati, dkk., 2008).

Widaningrum (2007) menyatakan bahwa logam berat yang masuk kedalam tubuh manusia akan melakukan interaksi dengan enzim dan protein termasuk DNA melalui proses metabolisme. Adanya jumlah logam berat yang berlebih dalam tubuh akan berpengaruh buruk terhadap tubuh, karena timbal dapat bersenyawa dengan enzim aktif menjadi tidak aktif, sehingga sintesis butiran darah manusia $(\mathrm{Hb})$ dapat dihambat akibatnya dapat menimbulkan penyakit anemia.

\section{KESIMPULAN}

1. Sayuran hijau yang diambil sebagai sampel yang dijual di pasar tradisional kampung lalang Medan mengandung logam berat timbal.

2. Kadar timbal tertinggi hingga terendah yang terdapat dalam sampel sayuran hijau sebelum dicuci yaitu, Pakchoi 1,0521 $\mathrm{mg} / \mathrm{kg}$, Kangkung 1,0246 mg/kg, Bayam hijau 0,9816 $\mathrm{mg} / \mathrm{kg}$, Sawi hijau 0,9681 mg/kg, Genjer $0,8654 \mathrm{mg} / \mathrm{kg}$, Brokoli 0,7502 mg/kg, Daun singkong $0,7355 \mathrm{mg} / \mathrm{kg}$.

3. Semua sampel sayuran berada di atas batas nilai maksimum cemaran logam berat timbal yang diperbolehkan oleh SNI 7387 tahun 2009 yaitu $0.5 \mathrm{mg} / \mathrm{kg}$.

\section{UCAPAN TERIMA KASIH}

Kiranya peneliti perlu mengucapkan terima kasih sebesar-besarnya kepada para rekan sejawat staf pengajar di jurusan Analis Kesehatan Poltekkes Medan yang banyak memberikan sumbang saran dan senantiasa memberikan dorongan kepada penulis hingga terselesaikannya penelitian ini.

\section{DAFTAR PUSTAKA}

Aini, M. N, 2015. Dahsyatnya Bumbu dan Sayuran Berkhasiat Obat. Yogyakarta:

Badan Standardisasi Nasional, 2009. Batas Maksimum Cemaran Logam Berat dalam Pangan. SNI 04-7387-2009. Penerbit: Badan Standardisasi Nasional (BSN).

Charlena, 2004. Pencemaran Logam Berat Timbal $(\mathrm{Pb})$ pada Sayur-sayuran. 
Skripsi. Bogor: Program Pascasarjana S3 IPB.

Dalimartha, S., \& Adrian, F, 2013. Fakta Ilmiah Buah Dan Sayur. Jakarta: Penebar Swadaya.

Darmono, 1995. Logam dalam Sistem Biologi Makhluk Hidup. Jakarta: Penerbit Universitas Indonesia (UI-Press).

Edi, S, dan Bobihoe, J. 2010. Budidaya Tanaman Sayuran. Jambi: Balai Pengkajian Teknologi Pertanian (BTPP) Jambi.

Erdayanti, P, 2015. Analisis Kandungan Logam Timbal pada Sayur Kangkung dan Bayam di Jalan Kartama Pekan Baru Secara Spektrofotometri Serapan Atom. Skripsi. JOM FMIPA.

Gandjar, I.G, dan Rohman, A. 2007. Kimia Farmasi Analisis. Cetakan Pertama. Yogyakarta: Pustaka Pelajar.

Indrasti, N.S., Suprihatin., Burhanudin., dan Novita, A. 2006. Penyerapan Logam Pb dan Cd oleh Eceng Gondok: Pengaruh Konsentrasi Logam dan Lama Waktu Kontak. Jurnal Teknologi Industri Pertanian.

Kariman, 2014. Bebas Penyakit Dengan Tanaman Ajaib. Surakarta:

Nuraini, D. N, 2014. Aneka Daun Berkhasiat Untuk Obat. Yogyakarta: Penerbit Gava Media.

Mariti, Q, 2005. Pemeriksaan Cemaran (Pb) Pada Daun Teh (Camellia sinensis L.O. Kuntze) yang Ditanam di Pinggiran Jalan di Daerah Alahan Panjang Sumatera Barat Secara Spektrofotometri Serapan Atom. Skripsi. Padang. FMIPA. Universitas Andalas.

Paeru, R. H., \& Dewi, T. Q, 2016. Bertanam Sayuran Di Pekarangan. Jakarta: Penerbit Swadaya.

Palar, H. 2004. Pencemaran dan Toksikologi Logam Berat. Cetakan Kedua. Jakarta: PT Rineka Cipta.

Pasaribu, I. H. 2004. Kadar Timbal (Pb) pada Beberapa Tanaman Sayuran Sebelum dan Sesudah Dimasak di Kota Medan dan Brastagi. Skripsi. Medan. Departemen Kesehatan Lingkungan FKM USU.
Perwitasari, B. Tripatmasari, M., dan Wasonowati, C, 2012. Pengaruh Media Tanaman Nutrisi Terhadap Pertumbuhan dan Hasil Tanaman Pakchoi(Brassica juncea L.) dengan Sistem Hidroponik. Jurnal Agrovigor.

Purnamasari, R.M. 2012. Analisis Timbal, Tembaga, Kadmium pada Daun danBatang Selada, Bayam Merah dan Genjer Secara Spektrofotometri Serapan Atom. Skripsi. Depok: Universitas Indonesia.

Puspitasari, P., Linda, R., dan Mukarlina. 2013.Pertumbuhan Tanaman Pakchoy dengan Pemberian Kompos Alang-Alang pada Tanah Gambut. Jurnal Protobiont.

harjo, D., Mustamir, E. dan Suryadi, U.E. 2012. Uji efektifitas beberapa jenis arang aktif dan tanaman akumulator logam pada lahan bekas penambangan. Jurnal Perkebunan dan Lahan Tropika.

Siregar, E.B.M, 2005. Pencemaran Udara, Respon Tanaman dan Pengaruhnya Terhadap Manusia. Karya Tulis Ilmiah. Medan. Fakultas Pertanian: Universitas Sumatera Utara.

Soedarsono, 2017 Tumpas Diabetes Dengan Buncis. Surabaya: Penerbit Stomata.

Sunarjono, H. 2015. Bertanam 36 Jenis Sayur. Jakarta: Penebar Swadaya.

Suryani, R, 2015. Hidroponik Budidaya Tanaman Tanpa Tanah. Yogyakarta: Penerbit Arcitra.

Widaningrum., dkk. 2007.Bahaya Kontaminasi Logam Berat dalam Sayuran dan Alternatif Pencegahan Cemarannya. Buletin Teknologi Pascapanen Pertanian.

Widowati, W., Sastiono, A., dan Jusuf, R. 2008. Efek Toksik Logam. Edisi Pertama. Yogyakarta: Andi OFFset.

Yuliarti, N. 2008. Hidup Sehat Dengan Sayuran. Yogyakarta: Cakrawala. 